\title{
PHYSIOLOGICAL AND BIOCHEMICAL BASES OF COCONUT PRODUCTION
}

\author{
By \\ V. RAJAGOPAL, KV KASTURIBAI, S. SHIVASHANKAR ${ }^{1}$
}

\begin{abstract}
The relevance of the physiological arid biochemical investigations on coconut production has been amply proved. The physiological data on the seedling characters arid the equations developed for leaf area arid dry matter production proved to be valuable tools for application in the nursery selections. The experimental evidence provided by the biochemical studies opened up new vistas for utilising some of the biochemical markers related to the processes of growth arid yield in coconut palms. The rapid screening technique developed for drought tolerance offers a good scope for evaluating the germplasm collections. That the scientific management practices could substantially enhance the yield potential of root (wilt) diseased palms has been convincingly delineated.
\end{abstract}

\section{INTRODUCTION}

The coconut palm exhibits wide variability in the production of nuts ranging from 30 nuts, 200 nuts palm-1 year-1, with elite (super) palms yielding even upto 400 nuts (Iyer et el. 1979). This variability may be attributed to genotypes arid their responses to the agronomic operations like water management arid fertilizer levels, soil factors such as sandy, laterite or clay soils arid to the prophylactic measures adopted against the disease arid pests. Weather factors namely sunshine hours, light intensity, ambient temperature, arid relative humidity and rainfall also contribute to the fluctuation in the yield of nuts (Murray, 1977). The ultimate yield of any crop depends on the efficiency of dry matter production arid its partitioning into economic produce. This can be assessed with an understanding of the physiological arid biochemical processes involved in the production of nuts in coconut palm, such as leaf area, photosynthesis, dry matter, carbohydrate levels, chlorophylls, enzymes arid nut characters.

\section{Physiological characters}

The selection of planting material is one of the important methods of crop improvement. In coconut, selection is made at two stages namely mother palm selection and seedling selection. Harland (1957) reported a wide variability in the transmittance of high yielding capacity to the progenies among the West Coast Tall (WCT) palms. The length of stem and number of leaves in the crown are significantly correlated with annual yield (Patel 1938). A higher rate of leaf production has been noticed in the bearing than in the non-bearing palms (Femond and Brunin 1966, Ramadasan and Mathew 1977). The seedlings which produce more number of leaves in the first two years of growth are found to be the early yielders.

The leaf area and shoot dry mass are the two important parameters which determine the production potential of crop plants (Watson 1952). However, partitioning of the total biological yield is an essential inherent character that determines the economic yield. Extensive work as been carried out in the case of oilpalm to study the growth related aspects (Rees and Tinker 1963, Hardon et al 1969, Corley et al 1976), while only limited reports are available on coconut (Pillai and Davis 1963, Ramadasan et al 1980, Ramadasan and Jacob Mathew 1987). The latter workers, who developed the

\footnotetext{
${ }^{1}$ Central Plantation Crops Research Institute, Kasaragod 671 124, Kerala, India.

Senior Plant Pathologist, Plant Physiologist and Biochemist, respectively, Central Plantation Crops Research Institute, India.
} 
regression equation for the estimation of leaf area and dry matter production observed that once the leaf is completely expanded no differences in the leaf area are noticed among the leaves. From the leaf area of a single leaf the total canopy area has been computed. The leaf area of the hybrids (Tall x Dwarf and Dwarf x Tall) ranges from $5.0 \mathrm{M}^{2}$ to $6.8 \mathrm{M}^{2}$ as against $4.5 \mathrm{M}^{2}$ to $5.5 \mathrm{~m}^{2}$ exhibited by the tall/dwarf parent. The dry weight of individual leaf ranges between 1.2 to $2.0 \mathrm{~kg}$.

The coconut palm with a single meristem at the shoot apex exhibits growth in terms of the emergence of leaves in succession. Only the newly emerged leaf shows active growth, before it is fully expanded and this rate of increase in leaf area and dry weight during a certain interval should provide an index for the efficiency of dry matter production. Since the amount of assimilate translocated from the leaf is not taken into consideration during the sampling interval as in the case of net assimilation rate determinations of annual crops, the values obtained would give only the relative efficiencies of dry matter production. This rate of increase in leaf area and dry weight of the growing leaf per unit time has been termed as relative assimilation rate (RAR). Ramadasan et al (1984) reported higher RAR in the hybrids than in the parents, and highly correlated with yield.

The coconut palm grows to a height of 10 to 24 meters with rough pitted fallen leaf scars, which encircle the whole stern. Roughly 12 to 14 such successive leaf scars correspond to the growth of the tree for one year. Ramadasan and Mathew (1987) developed regression equations for the non-destructive estimation of annual stern dry mass by using the parameters namely annual growth of the trunk and the number of leaf scars. The annual dry matter production of adult WCT palms, adopting the above method, ranged from 65 to $85 \mathrm{~kg}$ palm- 1 .

Shivashankar et al (1982) observed a higher leaf area coupled with higher rate of photosynthesis and lower dark respiration in tall x dwarf hybrid (WCT x COD) than the respective parents. The low yields among the dwarfs has been attributed to high rates of dark respiration in proportion to photosynthetic rates (Table 1). A similar trend was reported in the East Coast Tall (Raveendran et al 1989).

Table I : Rate of Apparent Photosynthesis Dark Respiration, Relative Assimilation Rate and Other Characters in Three Coconut Genotypes

\begin{tabular}{|c|c|c|c|c|c|c|}
\hline \multirow{2}{*}{ Parameters } & \multicolumn{2}{|c|}{ WCT } & \multicolumn{2}{|c|}{ COD } & \multicolumn{2}{|c|}{$T \times D$} \\
\hline & Mean & CV\% & Mean & CV\% & Mean & $\mathrm{CV} \%$ \\
\hline Rate of apparent Photosynthesis ( $\mathrm{LO}_{2}$ evolved $\left.\mathrm{cm}^{-2} \mathrm{~h}^{-1}\right)$ & 28.11 & 22.0 & 32.82 & 30.2 & $33.98 *$ & 14.0 \\
\hline Dark respiration (lo2, consumed $\mathrm{Cm}^{-2} \mathrm{~h}^{-1}$ ) & 4.23 & 24.4 & 6.31 & 11.8 & $5.02^{\star *}$ & 21.5 \\
\hline Relative assimilation Rate (g. $\mathrm{m}^{-2}$, week ${ }^{-1}$ ) & 2.83 & 44.1 & 2.63 & 38.8 & $4.7^{* *}$ & 23.4 \\
\hline Total Chlorophyll (mg. cm²) & 0.05 & 30.0 & 0.04 & 15.0 & $0.06^{\star *}$ & 16.0 \\
\hline Total carotenoids (mg cm-2) & 0.02 & 36.0 & 0.02 & 20.0 & $0.03^{* *}$ & 17.0 \\
\hline Stomatal frequency (NO. mm-2) & 199.06 & 10.3 & 189.5 & 19.3 & 203.59 & 14.0 \\
\hline Leaf area $\left(m^{2}\right.$ leaf-1 $)$ & 4.5 & - & 3.6 & - & $6.8^{\star \star}$ & - \\
\hline $\begin{array}{l}\text { Mean yield } \\
\text { (No: of nuts palm--1 year-1) }\end{array}$ & 58.3 & 26.4 & 48.6 & 33.3 & 93.1 & 51.5 \\
\hline
\end{tabular}

**Significant at $1 \%$ level.

* Significant at 5\% level.

Another important area in the production physiology of coconut is the development of inflorescence and fruit set. Although the number of female flowers produced vary depending on the genotypes, the percentage of fruitset is normally 35 to $40 \%$ but under abnormal conditions, the 
shedding of buttons/immature fruit increases leading to poor nut yield (Menon and Pandalai, 1958). Kasturibai and Ramadasan $(1982,1983)$ have shown the importance of assured level of carbohydrate fractions from the source (stem) to the sink (inflorescence) for the initiation and development of the inflorescence. Their work also revealed the influence of environmental variables on the carbohydrate levels and inflorescence development (Fig. 1). This is in support of earlier report on the adequate build up of carbohydrates in the stem as a pre-requisite for the commencement of first flowering (Ramadasan and Mathew, 1977)

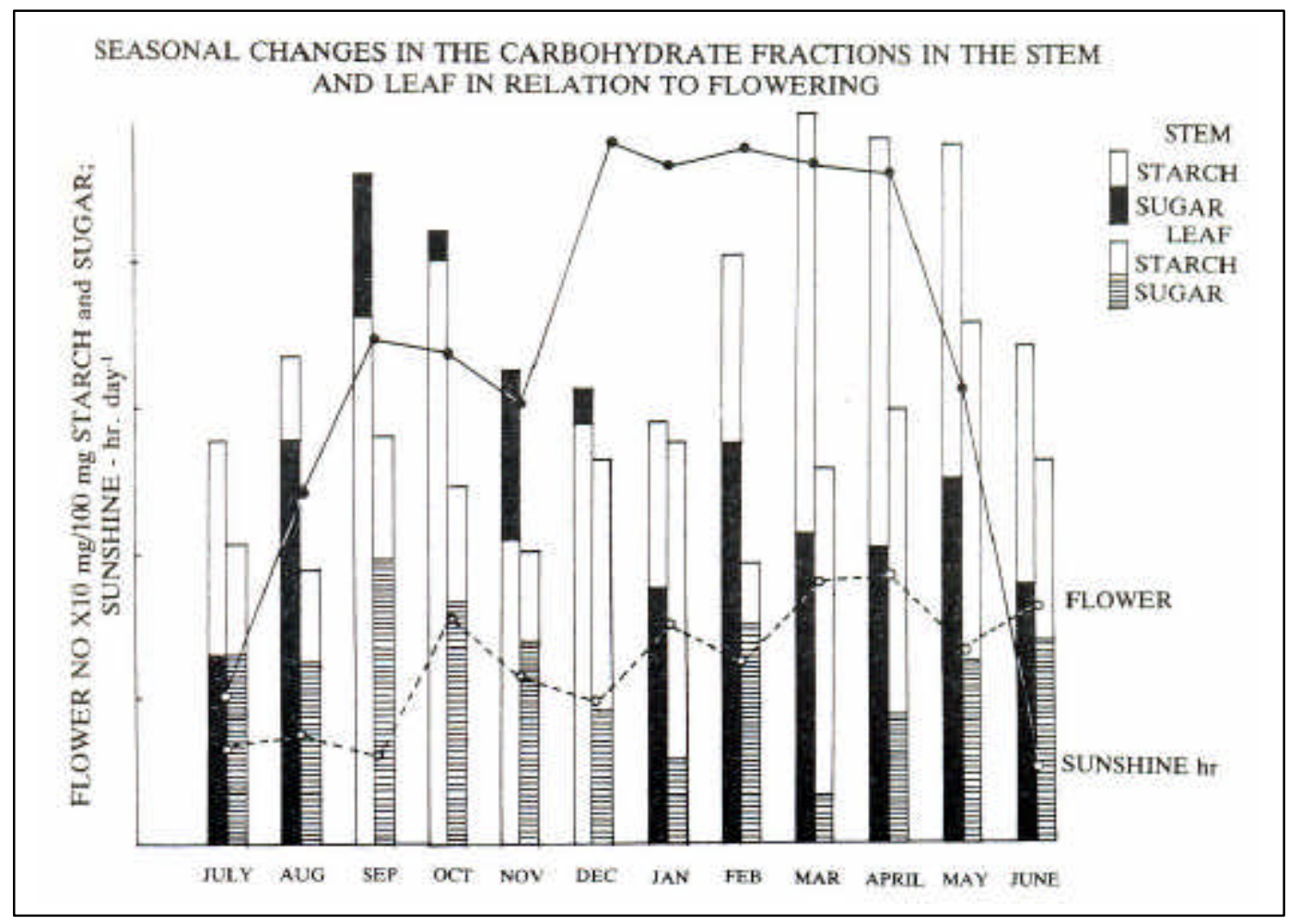

Since the harvest index is an important criteria in determining the genetic variability in biological and economic yields, attempts have been made to work out the index in coconut. By determining the partitioning of dry matter to the annual production of nuts from the annual, biological yield, the annual productivity index (API) has been worked out. The API thus estimated ranged from 0.4 to 0.5 in a group of palms in which the annual yield of nuts ranged from 45 to 91 nuts palm-1 year-1. The ratio showed a good relationship with annual yield of nuts and is a good index for determining the production efficiency of coconut palm (Ramadasan and Rajagopal 1987). According to Ramadasan et al 1985, the efficiency of dry matter production in coconut is a heritable character.

\section{Biochemical characters}

As plant growth and yield are also the manifestation of biochemical pathways, linked with the physiological processes explained in the earlier section, an attempt has been made to assess the relevant aspects in coconut. One of the limiting factors associated with the growth and productivity is the uptake and assimilation of nitrogen, the first among the major nutrients. The utilization of this important nutrient is determined by the activity of nitrate reductase (NR) enzyme which catalyzes the rate-limiting step namely the reduction of nitrate to nitrite in the sequence of reactions leading to the production of aminoacids. The in vivo activity of this enzyme has been positively correlated with the yield and protein content of several cereal crops (Hagemen, 1970; Eck et al 1975) and yield of tea (Wickremasinghe et al, 1980). 
Experiments in our laboratory indicated that NR activity in coconut leaves measured after substrate induction was significantly related to yield of nuts in a population of 150 palms belonging to low, medium and high yield groups (Fig. 2) (Shivashankar and Ramadasan 1983). Subsequent work on the inducibility of NR in low and high yielding palms subjected to a range of nitrate levels showed that in the high yielders the enzyme activity was two-fold higher than in the low yielders at the optimal substrate level. Further more, the nitrate concentration required for maximum induction was much less in high yielders $(80 \mathrm{~mm})$ than that for low yielders $(140 \mathrm{~mm})$ (Fig. 3), implying thereby the better utilization of the available nitrate by the high yielders than the low yielders (Shivashankar and Kasturibai 1989).

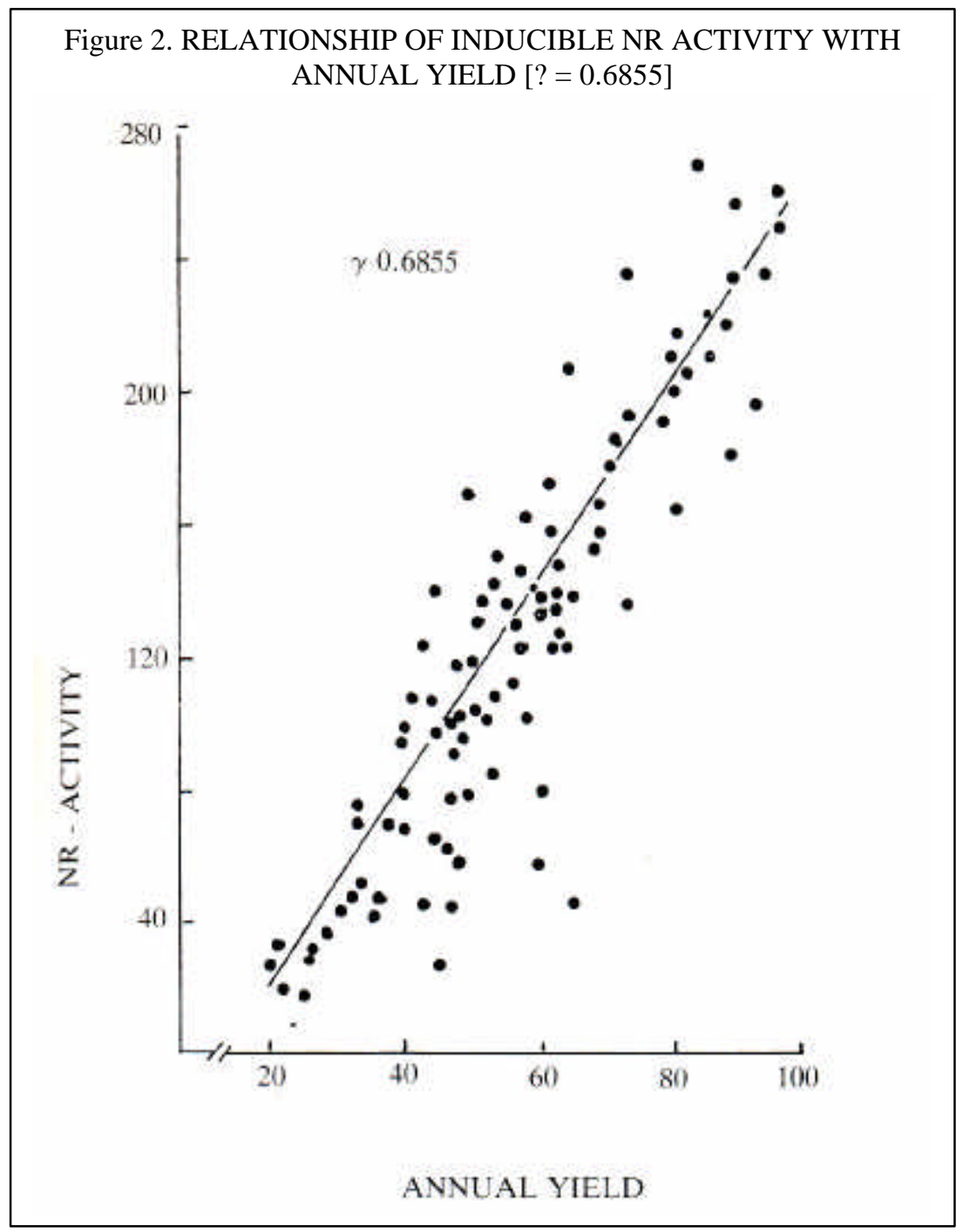

Further investigations centered around the assay of the enzyme in certain varieties and hybrids of genetically dissimilar nature, with the objective of relating the enzyme activity with growth parameters at nursery level itself. The F, progeny of Chowghat Orange (COD) and West Coast Tall (WCT) cross trend to be highly heterozygous with respect to the colour of the petiole and seedling vigour. From the Table (2) it is clear that the greenish brown coloured vigorous plants (heterotic hybrids) has higher content of chlorophylls $(a+b)$ and nitrate reductase activity as compared to the orange coloured vigorous plants (intermediate hybrids) and the dwarf segregants (dwarf hybrids). The shoot dry mass, an important index of vigour, was significantly and positively correlated with NR activity $(\mathrm{r}=0.55)$, reflecting the central role played by NR in the growth process. These results indicated that NR activity at the juvenile stage could serve as a sensitive predictor of 
the seedling vigour (Shivashankar et al, 1985). Further confirmation was obtained with the seedlings of three hybrid crosses, which revealed the superiority of MYDxWCT in growth attributes as compared to MOD x WCT and COD x WCT (Shivashankar and Kasturibai 1988). The hybrid MYD $\mathrm{x}$ WCT displayed a higher nitrogen use efficiency than the other two hybrids, which implies the better utilization of applied nitrogen by MYD x WCT (Table 3). The growth parameters followed over a period of five years have established the superiority of MYD x WCT which also showed early bearing habit (Shivashankar et al, unpublished).

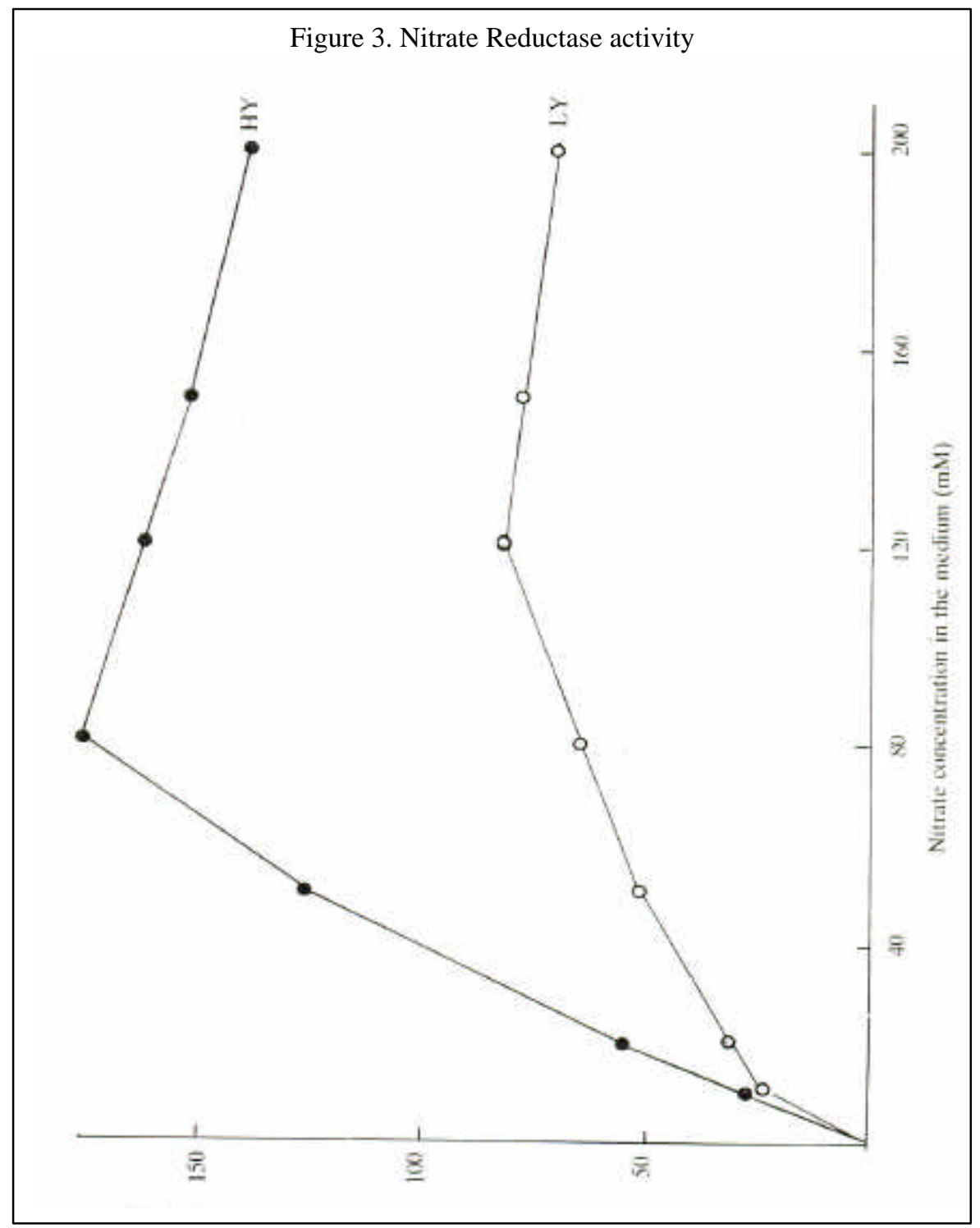

Table 2: Photosynthetic Pigments, Nitrate Reduction, Leaf area and Shoot dry in $\mathbf{F}_{\mathbf{1}}$ Hybrid Coconut Seedlings

\begin{tabular}{|l|c|r|r|r|r|r|}
\hline \multicolumn{1}{|c|}{ Type } & $\begin{array}{c}\text { Chlorophylls } \\
(\mathrm{a}+\mathrm{b})\end{array}$ & $\begin{array}{c}\text { Carotenoids } \\
\left(\mathrm{mg}^{\prime} / \mathrm{dm}^{2}\right)\end{array}$ & $\begin{array}{c}\text { NR activity } \\
\text { nimoles }\end{array}$ & $\begin{array}{c}\text { Reduced N } \\
(\mathrm{mg} / \mathrm{g})\end{array}$ & $\begin{array}{c}\text { Shoot dry } \\
\text { mass }(\mathrm{g})\end{array}$ & $\begin{array}{c}\text { Leaf area } \\
\left(\mathrm{m}^{2}\right)\end{array}$ \\
\hline Heterotic hybrid & 3.57 & 1.59 & 457.4 & 18.5 & 221.3 & 0.84 \\
Intermediate hybrid & 3.09 & 1.37 & 183.4 & 18.5 & 148.1 & 0.53 \\
Dwarf hybrid & 2.70 & 1.23 & 119.0 & 15.3 & 47.6 & 0.30 \\
\hline
\end{tabular}


Table 3: Nitrate Reduced and Nitrogen Accumulated by the Seedling Shoots in One Months After N - Application

\begin{tabular}{|c|r|r|r|r|r|}
\hline Hybrid & Total shoot N (g) & $\begin{array}{c}\text { Nitrate reduced } \\
\text { by shoot } \\
\text { (m moles) }\end{array}$ & $\begin{array}{r}\text { N contributed } \\
\text { Via. nitrate } \\
\text { reduction }(\mathrm{mg})\end{array}$ & $\begin{array}{c}\text { \%N by shoot NR } \\
\text { activity }\end{array}$ & $\begin{array}{c}\text { Nitrogen uptake } \\
\text { efficiency }\end{array}$ \\
\hline COD x WCT & 0.70 & 3.39 & 46.1 & 6.13 & 0.014 \\
MOD x WCT & 1.24 & 8.81 & 123.3 & 10.00 & 0.25 \\
MYD $\times$ WCT & 1.90 & 27.1 & 379.1 & 20.00 & 0.40 \\
\hline
\end{tabular}

** Significant at $1 \%$ level.

\section{Production Constraints}

The production of coconuts is hampered by factors such as drought, diseases or disorders. While yield decline is attributed to drought in some of the coconut growing countries, diseases like lethal yellowing in Jamaica, Cadang Cadang in Philippines and root (wilt) disease in India are reported to result in low production of nuts. A case study on the physiological approaches made on drought tolerance in coconut genotypes and root (wilt) disease is presented below.

Drought: As a rainfed crop coconut is exposed to vagaries of weather in countries like India. Rainfall has greater influence on the production of nuts. The differential response of yield by coconut to the monthly and seasonal rainfall was observed at Kasaragod and Pilicode (Balasubramanian 1956). Lakshmanachar (1953) reported the correlation between rainfall and nut yield. The important factor for the highest production of nuts is the better distribution of rainfall (Abeywardena 1969). A comparative study of the data on the climatic chahges and nut yield from four African countries indicated that water deficit plays an important role in yield fluctuations under non-limiting conditions of sunshine and temperature (Coomans 1975).

Frequent occurrence of drought even in heavy rainfall areas as in North Kerala, results in poor nut yield, emphasizing thereby the significance of effective rainfall in nut production. Rajagopal et al (1986) reported the response of two genotypes (WCT and COD x WCT) to low and high drought intensities (South and North Kerala respectively) on leaf characters and yield attributes. The impact of moisture stress on yield related processes like stomatal regulation dry matter partitioning has been investigated (Rajagopal et al 1989a). A soil water deficit of $110 \mathrm{~mm}$ was found to be the critical level at which coconut suffered most due to moisture stress in sandy loarn soil, is indicated by stomatal closure a sensitive indicator of plant stress. Exposure of palms to field stress for 16 or 24 days during summer led to a reduction in the vegetative dry matter by $15 \%$ and $18 \%$ respectively whereas the reproductive dry matter was reduced by $20 \%$ and $22 \%$ respectively, as compared to nonstressed i.e. irrigated palms. The number of days taken for unfolding of spindle leaf and the spathe was more during 'dry' than during 'wet' season both in WCT and COD x WCT palms, which reflects on the role of soil moisture availability on these important processes. During summer, atmospheric drought further aggravates the water relations of coconut palms (Kasturibai et al. 1989b).

When three genotypes namely WCT, WCT x COD and COD x WCT were compared under irrigated and rainfed conditions, the partitioning of dry matter into husk, shell and copra was affected due to stress (rainfed) more in COD x WCT than in the other two genotype, revealing thereby the drought susceptible nature of COD x WCT (Anonymous, 1987).

Prasada Rao (1985) worked out the aridity index based on which drought classification was made to assess the extent of damage to coconut palms. Accordingly, an aridity index of $85 \%$ that 
occurred during March 1983 was associated with drying of leaves, preceded by drooping sympton. Varietal differences exist among coconut palms in the number of dry and broken leaves (Pomier and de Taffin 1982, Rajagopal et al 1990b). Besides leaf characters, poor spathe development and shedding of unfertilized female-flowers (buttons) and immature nuts are characteristic features of drought affected palms. Ramadasan et al (1991) reported the response of ten coconut genotypes to the severe drought of 1982-1983 (Table 4). When ail the three characters recorded, namely leaf and bunch conditions and nut fall were compared, WCT x MOD appeared to be more affected, followed by COD x WCT while other genotypes exhibited the impact on one or two characters only. In general, WCT x COD, LO x COD, WCT x GB, WCT x FIJI, WCT x Kappadam, besides WCT are relatively tolerant to drought. The screening techniques adopted in the authors' laboratory also indicated the drought tolerant nature of some of the above genotypes (Rajagopal et al 1990a). The better yield performance of the drought tolerant LO x GB, LO x COD, WCT x COD than the other genotypes, further confirmed the efficacy of screening techniques (Rajagopal et al $1990 \mathrm{c}$ ). Further evidence on drought tolerance was obtained through biochemical characterization of the genotypes (Shivashankar 1988, Shivashankar et al 1991, Shivashankar 1990).

Table 4: Effect of Drought on Coconut Leaves, Bunches and Nuts

\begin{tabular}{|c|c|c|c|c|c|c|c|c|c|}
\hline \multirow{2}{*}{ Cultivars } & \multicolumn{2}{|c|}{ Leaves } & \multirow{2}{*}{$\begin{array}{l}\text { Drought } \\
\text { index* }\end{array}$} & \multicolumn{3}{|c|}{ Bunches } & \multicolumn{3}{|c|}{ Nuts } \\
\hline & $\begin{array}{c}\text { Dryl } \\
\text { broken }\end{array}$ & Total & & Affected & Total & $\%$ & Fallen & Total & $\%$ \\
\hline WCT x COD & 6.4 & 29 & 22.1 & 7.6 & 14.3 & 53.1 & 39 & 135 & 28.9 \\
\hline COD x WCT & 10.2 & 20 & 51.0 & 9.2 & 14.6 & 63.0 & 40 & 103 & 38.8 \\
\hline LO x COD & 5.5 & 23 & 23.9 & 6.0 & 12.5 & 48.0 & 21 & 66 & 31.8 \\
\hline WCT x GB & 2.5 & 21 & 11.9 & 9.0 & 13.5 & 66.7 & 33 & 105 & 31.4 \\
\hline WCT x Fiji & 5.0 & 29 & 17.2 & 2.0 & 15.0 & 13.3 & 39 & 142 & 27.5 \\
\hline WCT x SSG & 8.0 & 24 & 33.3 & 11.0 & 14.0 & 78.6 & 43 & 127 & 33.8 \\
\hline WCT x Philiord. & 0 & 24 & 0 & 12.0 & 17.0 & 70.6 & 40 & 134 & 29.8 \\
\hline WCT x Kappadam & 7.0 & 23 & 30.4 & 10.0 & 15.0 & 66.7 & 12 & 77 & 15.7 \\
\hline WCT x MOD & 11.0 & 17 & 64.7 & 10.0 & 11.0 & 90.9 & 18 & 50 & 36.0 \\
\hline WCT & 6.8 & 23 & 29.5 & 6.0 & 13.0 & 46.1 & 23 & 101 & 22.8 \\
\hline WCT (Irrigated) & 0 & 28 & 0 & 0 & 13.5 & - & 5 & 108 & 4.6 \\
\hline
\end{tabular}

* Method of Pomier and Taffin, 1982.

Disease: Among the coconut diseases in India, root (wilt) disease of mycoplasmal etiology, in Kerala state ranks high in terms of the spread and decline in nut yield. It is estimated that 968 million nuts are lost from the affected palms (Anonymous 1985). The disease is characterized by flaccidity, yellowing and necrosis of leaves of different intensities, which in physiological terms would amount to reduction in effective photosynthetic area. Reduction in nut yield in the disease affected palms was found to be proportionate to the intensity of the disease (Anonymous 1976). From a comprehensive field experiment on the response of diseased palms to management practices involving summer irrigation, fertilizer application and prophylactic measures, Rajagopal et al 1987, 1989b) reported a marked decline in the number of yellow leaves, senescent leaves and rotten leaves between the pre and post treatment stages. This means that the greenness of leaves increased in well managed palms, resulting in higher photosynthetic area than those palms, which were poorly managed (Table 5). These resulted in significant improvement in the production and quality of nuts of palms subjected to management practices. 
Table 5: Effective Photosynthetic Area in Root (wilt) Diseased Coconut Palms Under Different Management Practices. Leaf area, $\mathrm{m}^{2}$ palm ${ }^{-1}$

\begin{tabular}{|l|l|c|c|c|r|}
\hline Treatment & \multicolumn{1}{|c|}{ Stage } & Yellowing & \multicolumn{1}{c|}{ Rot } & Senscence & Average \\
\hline $1_{1} \mathrm{~F}_{1}$ & Pre-treatment & 69.5 & 29.4 & 25.8 & 41.6 \\
& Post-treatment & 28.6 & 17.4 & 10.2 & 18.6 \\
& $\%$ & 59.4 & 40.9 & 60.5 & 44.7 \\
& & & & & \\
$\mathrm{I}_{0} \mathrm{~F}_{1}$ & Pre-treatment & 51.5 & 27.0 & 22.2 & 33.6 \\
& Post-treatment & 55.7 & 17.4 & 18.6 & 30.6 \\
& $\%$ & 108.6 & 35.6 & 16.2 & 91.1 \\
& & & & & \\
$\mathrm{I}_{0} \mathrm{~F}_{0}$ & & 73.7 & 34.1 & 30.6 & 46.1 \\
& Pre-treatment & 76.1 & 31.8 & 34.1 & 47.3 \\
& Post-treatment & 103.3 & 106.7 & 111.4 & 102.6 \\
\hline
\end{tabular}

\section{Thrust Areas of Research:}

Major areas of activity for future research could be broadly outlined based on the results presented :

(i) Relationship between the seedling characters and nut yield of adult palms.

(ii) Photosynthesis and nitrogen metabolism in relation to productivity.

(iii) Biochemical markers as indicators of yield potential, drought tolerance etc.

(iv) Mechanism of drought tolerance and future strategies for breeding programme.

\section{ACKNOWLEDGEMENTS}

We are grateful to Dr. KV Ahmed Bavappa, Ex-Director and Dr. MK Nair, Director CPCRI for the encouragement and facilities in the investigations. Our thanks are due to the Head of Divisions of Agronomy and Genetics for providing the experimental materials and to the Head of Statistics for the analysis. 


\section{REFERENCES}

ABEYWARDANA, V (1969) "Forecasting coconut crops using rainfall data a preliminary study" Ceylon Coconut Quarterly 19, 161-176.

ANONYMOUS, (1976). Annual report of Central Plantation Crops Research Institute for 1975 p 19.

ANONYMOUS (1985). Coconut root (wilt) disease Intensity, production loss and future strategy. CPCRI, Kasaragod. pp. 45.

ANONYMOUS (1987). Annual report of Central Plantation Crops Research Institute for 1987. pp. 49-50.

BALASUBRAMANIAN C. (1956). "Rainfall yield of coconut in S. Kannara Dt. Indian Coconut Journal. 9, 207-214.

BEEVERS, L and HAGEMAN, R.H. (1969). Nitrate reduction in higher plants. Annual Review of Plant Physiology 20, 495-522.

COOMANS, P. (1975). Influence of climatic factors on seasonal and annual fluctuations in the coconut yield. Oleagineux 30 (4), 153-159.

CORLEY, R.H.V., HARDON, J.J., and WOOD, D.J. (1976). Development in Crop Science - 1. Oil palm Research Elsevier Scientific publishing Co. Amsterdam pp. 532.

CROY, L.I. and HAGEMAN, R.H. (1970). Relationship of nitrate reductase activity to grain protein production in wheat. Crop Science 10, 280-285.

ECK, H.V., WILSON, G.C. and MARTINEZ, T. (1975). Nitrate reductase activity of grain sorghum leaves as related to yields of grain dry matter and nitrogen. Crop Science 15, 557-561.

FREMOND, Y and BRUNIN, C (1966). Leaf production and earliness in the young coconut palm. Oleagineux 21, 213-216.

HAGEMAN, R.H., LENG, E.R. and DUDLEY, J.W. 1967. A biochemical approach to corn breeding. Advances in Agronomy 19, 45-86.

HARDON, J.J., WILLIAMS, C.N. and WATSON, I (1969). Leaf area and yield in oil palm in Malaysia. Experimental Agriculture 5, 25-52.

HARLAND, S.C (1957). Circulation paper No. 7/57, Bull. No. 15, Coconut Research Institute, Sri Lanka.

IYER, R.D., BHASKARA RAO, ENN., and GOVINDANKUTTY M.P (1979). Super yielders in coconut. Indian Fmg. 28 (10):3-5.

KASTURI BAI, KN. and RAMADASAN, A. (1982). Changes in the carvigtdrate fractions in relation to female flower production in coconut. Journal of Plantation Crops 10(2), 124-126.

KASTURI BAI, K.V. and RAMADASAN, A. (1983). Changes in the levels of carbohydrate as a function of environmental variabilities in hybrids and tall coconut palms, In Coconut Research and Development (ed) N.M. Nayar, Wiley Eastern Limited pp. 203-209. 
KASTURI BAI, K.V., VOLETI, S.R. and RAJAGOPAL, V. (1988). Water relation of coconut palms as influenced by environmental variables. Agricultural and forest meteorology 43, 193-199.

LAKSHMANACHAR, M.S. (1963). Studies on the effect of rainfall on coconut crops. Indian Coconut Bulletin 16, 370-372.

MENON, K.P.V. and PANDALAI, K.M. (1958). The coconut palm. A monograph. The Times of India Press, Bombay 293-303.

MURRAY, D.B. (1977). Coconut palm. In Ecophysiology of Tropical crops. (eds T.A. Alvim and T.T. Kozlowski. Academic Press. New York 384-407.

PATEL, J.S. (1938). The Coconut. A monograph Govt. Press. Madras pp. 102.

PILLAI, N.G. and DAVIS, T.A. (1963). Exhaust of nutrients by the coconut palm - a preliminary study. Indian Coconut Journal 16, 81-87.

POMIER, M. and DE TAFFIN, G. (1982). The tolerance to drought of some coconut hybrids Oleaginux 37, (2), 55-62.

PRASADA RAO, G.S.L.H.V. (1985). Drought and coconut palm. Indian Coconut Journal 15 (12), 3-6.

RAJAGOPAL V, KASTURIBAI KV, RAMADASAN A, BALASIMHA D, VOLETI SR, PATIL KD, AMMA BSK, VARKEY T, MATHEW AS and GOPALAKRISHNAN NAIR M (1986). Leaf characteristics and dry matter production in coconut grown under conditions of low, and high drought intensities. Proc. Sym. on the 'Impact of Drought on Plantation Crops', CPCRI Kasaragod. Extended Summary, pp. 33-34.

RAJAGOPAL V, PATIL KD and SUMANTHY KUTTY AMMA, B. (1987). Efficacy of management practices for increasing the productivity of root (wilt) affected palms. Indian Coconut J. 18: 1-4.

RAJAGOPAL, V., RAMADASAN, A, KASTURI BAI, K.V., and BALASIMHA D (1989a). Influence of irrigation on leaf water relations and dry matter production in coconut palms. Irrigation science 10.73-81.

RAJAGOPAL, V. PATIL KD, MATHEW C and SUMATHY KUTTY AMMA B (1989b). Physiological studies on root (wilt) diseased coconut palms under different management practices. J. Plantation Crops 16 (Suppl.) 47-53.

RAJAGOPAL, V. KASTURI BAI, K.V. and VOLETI, S.R. (1990a). Screening of coconut genotypes for drought tolerance Oleagineux 45(5) 215-223.

RAJAGOPAL, V., KASTURI BAI, K.V., VOLETI, S,R. and SHIVASHANKAR, S. (1990b). Water stress in coconut palms (Cocos nucifera, L) Proc. of International Congress of Plant Physiology Vol. 1 (eds) S.K. Sinha, P.V. Sane, S.C. Bhargava and P.K. Agrawal. IARI New Delhi pp. 508-512.

RAJAGOPAL, V., KASTURI BAI, K.V. PILLAI, R.V. and VIJAYAKUMAR, K. (1990c). Relationship between Physiological characters and yield in coconut genotypes under rainfed condition in Pr. PLACROSYM IX held at Bangalore. Dec. 4-6 1990. Abst. No. 69, pp. 67. 
RAMADASAN, A. and JACOB MATHEW (1987). Leaf area and dry matter production in adult coconut palms Journal of Plantation Crops 15(1), 59-63.

RAMADASAN, A. and MATHEW C. (1977). Relationship of the carbohydrate reserve in the trunk with commencement of flowering in young West Coast Tall coconut palms. Journal of Plantation Crops 5, 125-126.

RAMADASAN, A. and RAJAGOPAL, V. (1987). Physiology of Coconut palm. In Tree physiology (ed) M.R. SETHURAJ, Elsevier Science publishers, B.V., Amsterdam. The Netherlands.

RAMADASAN, A., SATHEESAN, K.V. and BALAKRISHNAN, R. (1980). Leaf area and shoot dry weight in coconut seedling selection. Indian Journal of Agricultural Science. 50, 553-554.

RAMADASAN, A., MATHEW, C., JACOB MATHEW and SATHEESAN, K.V. (1984). Relative assimilation rate (RAR) in coconut palms. Journal of Plantation Crops. 12, 186-188.

RAMADASAN, A., KASTURI BAI, K.V., SHIVASHANKAR, S. and VIJAYAKUMAR, K (1985). Heritability of seedling vigour in coconut palms. Journal of Plantation Crops 13, 136-138.

RAMADASAN, A., BALAKRISHNAN, T.K. and RAJAGOPAL, V. (1990). Response of coconut genotypes to drought. Indian Coconut Journal (in press).

RAVEENDRAN, T.S. VIJAYARAGHAVAN, H. and RAMACHANDRAN, T.K. (1989). Some physiological aspects and production trends of certain coconut hybrids and their parents. $\operatorname{Cocos} 7,36-41$.

REES, A.R. and TINKER, P.B.H. (1963). Dry matter production and nutrient content of Plantation Oil palm in Nigeria. 1. growth and dry matter production. Plant and soil 19, 19-32.

SHIVASHANKAR, S. (1990). Studies on soluble enzyme systems of coconut (cocos nucifera, L) Cultivars. Ph. D. Thesis (Mysore University).

SHIVASHANKAR, S and KASTURI BAI, K.V. (1988). A comparative study of the growth and nitrogen accumulation capacity of hybrid Coconut (Cocos nucifera, L) seedlings. The Philippines journal of Coconut studies. XII(1) 24-29.

SHIVASHANKAR, S and KASTURI BAI, K.V. (1989). Ammonium enhances the nitrate reductase activity in coconut (Cocos nucifera, L) Leaves. Journal of Plantation Crops 16 Supplement) $55-60$.

SHIVASHANKAR, S and RAMADASAN, A (1983). Nitrate reductase activity in coconut leaves. Journal of the Science of Food and Agriculture. 34, 1179-1184.

SHIVASHANKAR, S., KASTURIBAI, K.V. and RAMADASAN, A. (1982). A comparative study of coconut genotypes for components of Photosynthesis and respiration. In Proceedings PLACROSYM V (ed) R.D. Iyer pp. 231-234.

SHIVASHANKAR, S. KASTURI BAI, K.V. and RAJAGOPAL V. (1991). Leaf water potential, stomatal resistance and activity of enzymes during the development of moisture stress in the coconut palm. Tropical Agriculturist (in press). 
SHIVASHANKAR, S., RAJAGOPAL, K and RAMADASAN A (1985). Chlorophylls and nitrate reductase activity in relation to heterosis in coconut seedlings. Ann. Bot. 55, 755-758.

WATSON, D.J. (1952). The physiological basis of variation in yield. Advances in Agronomy 4, 101-145.

WICKREMASINGHE, R.L. FERNANDO, V and EKANAYAKE, A. (1980). Nitrate reductase of tea as an indicator of yield and effect of mulching material. Plant and Soil 55, 3-7.

\section{DR. V. RAJAGOPAL}

Dr. V. Rajagopal, a senior plant pathologist at the Institute, has 24 years research experience, 11 years of which are in coconuts. Stress physiology and growth hormones are his special fields. He has contributed to the research on understanding of water relations of root (wilt) disease and drought tolerance in coconut. Dr. Rajagopal has published 70 research papers, 20 of which are on the subject of coconut.

\section{DR. S. SHIVASHANKAR}

Dr. S. Shivashankar is a biochemist at the Central Plantation Crops Research Institute since 1978. His main fields of activity are in evolving biochemical indices for selection of high yielders from nursery and screening for drought tolerance in coconut. He has published 15 research papers on the biochemical aspects of coconut.

\section{K.V. KASTURI BAI}

Mrs. K.V. Kasturi Bai is a plant physiologist with 16 years research experience in coconut concerning the physiology of flowering, growth and development and drought resistance. She has written about 20 scientific articles on coconuts. 